\title{
Revisiting the "First" Gilded Age: Business and Politics in the Late Nineteenth-Century United States
}

Evelyne Payen-Variéras and Nicolas Barreyre

\section{(2) OpenEdition \\ 1 Journals}

Electronic version

URL: https://journals.openedition.org/transatlantica/6475

DOI: 10.4000/transatlantica.6475

ISSN: $1765-2766$

Publisher

Association française d'Etudes Américaines (AFEA)

\section{Electronic reference}

Evelyne Payen-Variéras and Nicolas Barreyre, "Revisiting the "First" Gilded Age: Business and Politics in the Late Nineteenth-Century United States", Transatlantica [Online], 1 | 2013, Online since 16

February 2014, connection on 01 February 2023. URL: http://journals.openedition.org/transatlantica/ 6475 ; DOI: https://doi.org/10.4000/transatlantica.6475

This text was automatically generated on 1 February 2023.

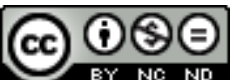

Creative Commons - Attribution-NonCommercial-NoDerivatives 4.0 International - CC BY-NC-ND 4.0 https://creativecommons.org/licenses/by-nc-nd/4.0/ 


\title{
Revisiting the "First" Gilded Age: Business and Politics in the Late Nineteenth-Century United States
}

\author{
Evelyne Payen-Variéras and Nicolas Barreyre
}

This dossier is dedicated to Naomi Wulf, who generously (as was her habit) lent support, energy and countless advice to the organization of the symposium where these assembled articles were first presented.

1 The phrase "Gilded Age" has made a comeback in the past few years: the financial scandals of the early 2000's, the reckless practices of some businessmen and bankers, the giant mergers, have conjured up memories of the late-nineteenth century United States. The first "Gilded Age," an expression we owe to the satirical genius of Mark Twain and his co-author Charles Dudley Warner, still smacks of venality, incestuous relations between business and politics, and anti-democratic scheming by a class of plutocrats. Today's controversies have revived this whole imagery. ${ }^{1}$

2 Ironically, the new vogue of the "Gilded Age" label in contemporary commentary has happened while historians have been trying to get rid of this characterization of the period between Reconstruction and the turn of the twentieth century. After all, Americans did not use "Gilded Age" to describe their own times. ${ }^{2}$ The notions of corruption and reform have proved difficult to pin down, even though many contemporaries insisted they were real. ${ }^{3}$ Moving beyond the controversies of the midtwentieth century, social and cultural historians have explored new themes, such as the development of a consumer society or the upheavals caused by unbridled industrial growth. ${ }^{4}$ Business historians have highlighted the rise of a managerial class and explored the history of small firms. ${ }^{5}$

3 Yet these works most often elude the crux of the critique implied in the phrase "Gilded Age", which still questions our understanding of the changing links between democracy and capitalism in the United States of the late nineteenth century. These links were extensive and multifaceted, as being a politician was not incompatible with 
the pursuit of business enterprise. The transformations of both business and politics also affected the activities of professionals, especially lawyers and journalists, and presented them with new opportunities and new problems.

4 In fact, new efforts to reconceptualize the period insist on the articulation between economic transformations and the workings of the political system. ${ }^{6}$ They epitomize a renewed interest in political economy in historical scholarship. Stemming from political science, ${ }^{7}$ from cultural history,${ }^{8}$ or from business history, ${ }^{9}$ these new works recover how invested Americans were in shaping and controlling their economic destinies.

Building on this impulse, this issue of Transatlantica explores new approaches to the relations between businessmen and politicians, or more generally between the business world and the political sphere. It does not focus on corruption-even though this theme has enjoyed a comeback of sorts in the historiography ${ }^{10}$-but instead on the destabilization and redefinitions of the ties between these overlapping groups. All four articles underline the experimentations, the tinkering, and the conflicts that characterized those decades, and that the Progressive efforts at reform aimed to bring under control. Hailing from different fields-business history, legal history, media history and art history-they converge on the articulation between the actions of businessmen and their relations to the political world writ large.

The first article proposes an analysis of the relations between entrepreneurs and local notables, through a case study focusing on the promoters of the Central Pacific Railroad Co. Évelyne Payen-Variéras highlights the importance of partnership agreements and credit relations in the business transactions of the entrepreneurs who rose to prominence during the Civil War and its aftermath. She uncovers a flexible pattern of transactions management in which the pursuit of entrepreneurial independence and operating efficiency coexisted with the search for political influence. The California railroad promoters constantly revised the terms of their arrangements with local suppliers, professionals and newspapermen. The article calls on historians to analyze such practices instead of dismissing them as anecdotes of greed or temporary lapses in the march of progress.

7 With Paul Kens's paper, we can see how the activities of Gilded Age entrepreneurs did not simply raise questions of abusive influence over political institutions, but led both politicians and professional groups like lawyers and judges to reconsider the principles that shaped their own, specific practices. Through a close analysis of the history of the 1877 Munn v. Illinois case, Kens shows how politicians and lawyers fought over the meaning of fundamental notions like property rights, due process of law, and popular sovereignty. The decision of the U.S. Supreme Court in the Munn case should not be viewed simply as an incomplete or immature version of the modern corporate law doctrines. Justices Morrison Waite and Stephen Fields both accepted the fundamental premises of the American legal and political tradition, which provided citizens with guarantees against abuse of government power. However, they revisited this tradition in sharply different ways.

8 Like lawyers, newspaper publishers and editors could be partners to both politicians and entrepreneurs. Dominique Pinsolle shows how a variety of business and political interests coalesced around newspapers, news agencies and telegraph companies on both sides of the Atlantic Ocean. Between 1883 and 1885, the editors of Le Matin in Paris were backed by the American press magnate James Gordon Bennett, Jr. and his ally, the 
"Silver King" John W. MacKay, who together had formed an independent cable company. The story of the successive, short-lived partnerships between the editors of Le Matin and their financial backers suggests that business relations within the American entrepreneurial networks in France were at least as stormy as they were in the United States. It also suggests that the political savvy of American businessmen, and their use of the press for political influence, proved difficult to export to other contexts.

9 Finally, Michaël Vottero reminds us that Gilded Age entrepreneurs were also art collectors, and especially collectors of late-nineteenth century French paintings. They bought art on the occasion of their business trips to Europe, and also induced European art dealers to set up branch offices in the United States. Through a description of these art collections and a comparison between private collections and public commissions, Michaël Vottero provides an original account of the complex rivalry between business and political elites in the Gilded Age: while successful entrepreneurs were involved in the making of a new international market for "modern" art, office-holders were constrained by the standards of patriotism and republican frugality, which continued to hold sway until the Progressive Era.

\section{NOTES}

1. Mark Twain and Charles Dudley Warner, The Gilded Age: A Tale of Today, Hartford, American Pub. Co., 1873.

2. "Should We Abolish the 'Gilded Age'?", forum, Journal of the Gilded Age and Progressive Era 8, no. 4 (2009), 461-85.

3. Edward L. Glaeser and Claudia Dale Goldin, eds., Corruption and Reform: Lessons from America's Economic History, Chicago, University of Chicago Press, 2006; Mark W. Summers, The Era of Good Stealings Oxford, Oxford University Press, 1993; Id., Party Games: Getting, Keeping, and Using Power in Gilded Age Politics, Chapel Hill, University of North Carolina Press, 2004; Richard R. John, "Robber Barons Redux: Antimonopoly Reconsidered," Enterprise \& Society 13, no. 1 (2012), 1-38.

4. Charles W. Calhoun, The Gilded Age: Perspectives on the Origins of Modern America, $2^{\text {nd }}$ ed., Lanham, Md.: Rowman \& Littlefield, 2007; Rebecca Edwards, New Spirits: Americans in the "Gilded Age," 1865-1905, $2^{\text {nd }}$ ed., Oxford: Oxford University Press, 2011; Jackson Lears, Rebirth of a Nation: The Making of Modern America, 1877-1920, New York: HarperCollins, 2009.

5. Alfred D. Chandler, The Visible Hand: The Managerial Revolution in American Business, Cambridge, Mass, Belknap Press, 1977; Naomi R. Lamoreaux, Daniel M.G. Raff and Peter Temin, "Beyond Markets and Hierarchies: Toward a New Synthesis of American Business History," American Historical Review, vol. 108 (2), April 2003, 404-433; John K. Walton, "New directions in business history: Themes, approaches and Opportunities," Business History, vol. 52 (1), February 2010, 1-16. 6. Richard Schneirov, "Thoughts on Periodizing the Gilded Age: Capital Accumulation, Society, and Politics, 1873-1898," The Journal of the Gilded Age and Progressive Era 5, no. 3 (2006), 189-224.

7. E.g. Richard Franklin Bensel, The Political Economy of American Industrialization, 1877-1900 Cambridge, Cambridge University Press, 2000. 
8. E.g. Gretchen Ritter, Goldbugs and Greenbacks: The Antimonopoly Tradition and the Politics of Finance in America, Cambridge, Cambridge University Press, 1997; Heather Cox Richardson, West from Appomattox: The Reconstruction of America After the Civil War, New Haven, Yale University Press, 2007.

9. E.g. Richard R. John, Network Nation: Inventing American Telecommunications, Cambridge, Mass, Belknap Press of Harvard University Press, 2010.

10. Richard White, Railroaded. The Transcontinentals and the Making of Modern America, New York: W.W. Norton, 2011. 